\title{
MANAGEMENT OF PUBLIC INFORMATION DISCLOSURE IN INDONESIAN AUTONOMOUS UNIVERSITY: CASE STUDY IN UNIVERSITAS BRAWIJAYA
}

\author{
Muhammad Rosyihan Hendrawan ${ }^{1 *}$ and Gani Nur Pramudyo ${ }^{2}$ \\ ${ }^{1}$ Department of Library and Information Science, Universitas Brawijaya, Malang, Indonesia \\ ${ }^{2}$ Department of Library and Information Science, Universitas Indonesia, Jakarta, Indonesia
}

*Correspondence: mrhendrawan@ub.ac.id

\begin{abstract}
This study aimed to understand, describe, and analyze the management of public information disclosure, support and inhibiting factors, and efforts to improve the management of public information disclosure in one of the autonomous universities, Universitas Brawijaya (UB). This study uses the case study method with a qualitative approach. This study adopted a participative observation, in-depth interviews with five key informants, collecting documents, and audio-visual material to collected data. The finding of this study shows that management of public information disclosure in UB refers to Public Information Disclosure Number 14 the Year of 2008 (UU KIP). It refers to Regulation from Minister of Education and Culture Number 75 the Year of 2016 about Public Information Services in Universities that are provided through integrated service information center (PINTER) UB. UB also provided service of complaints and community satisfaction surveys. Management of Public Information Disclosure in UB influenced by the existence of supporting factors from UB manager and e-complaint system and internet network to support services activity. In contrast, the inhibiting factors are arising from lack of management in faculty or work unit and the lack of socialization from Information and Documentation Management Officer (PPID / IDMO) and Information, Documentation, and Complaints Center (PIDK / IDCC) to the academic communities. It made service yet utilized optimally. Besides, the efforts to improve the management of public information disclosure always carried out to improve service quality such as 1) establish good relations between staff, enhancing coordination between faculties and work units, 2) Increasing coordination with Manager and Quality Assurance Unit (QUA), 3) Using new regulation the Minister of Administrative and Bureaucratic Reform Number 14 of 2017, and 4) Adding three-division managers, such as Manager of information services, the Manager of user complaints and survey, and Manager of verification and data integration mapping.
\end{abstract}

Keywords: Public information disclosure, Information management, Information and documentation management officer, Autonomous university

\begin{abstract}
ABSTRAK
Penelitian ini bertujuan untuk memahami, mendeskripsikan, dan menganalisis pengelolaan, faktor pendukung, faktor penghambat, serta upaya peningkatan pengelolaan keterbukaan informasi publik di perguruan tinggi negeri badan hukum (PTN BH) di Indonesia. Dalam penelitian ini, peneliti mengambil studi kasus pada Universitas Brawijaya (UB). Metode yang digunakan dalam penelitian ini adalah studi kasus dengan pendekatan kualitatif. Pengumpulan data dilakukan dengan cara observasi partisipatif, wawancara mendalam pada lima informan kunci, pengumpulan dokumen, dan pengumpulan audio-visual. Hasil penelitian ini menunjukkan bahwa pengelolaan keterbukaan informasi di UB sudah sesuai dengan Undang-undang Keterbukaan Informasi Publik Nomor 14 Tahun 2008 (UU KIP) dan Peraturan Menteri Pendidikan dan Kebudayaan Nomor 75 Tahun 2016 tentang Layanan Informasi Publik yang dilayankan melalui Pusat Informasi Layanan Terpadu (PINTER) UB. UB menyediakan layanan keluhan dan survei kepuasan masyarakat. Pengelolaan keterbukaan informasi publik dipengaruhi faktor dukungan dari pimpinan UB, sistem e-complaint dan jaringan internet untuk memberikan pelayanan prima kepada pengguna. Adapun faktor penghambat yang muncul yaitu rendahnya pengelolaan data yang dilakukan oleh fakultas dan unit kerja, dan kurangnya sosialisasi dari Pejabat Pengelola Informasi dan Dokumentasi (PPID) dan Pusat Informasi, Dokumentasi, dan Keluhan (PIDK) kepada sivitas akademik menyebabkan kurangnya pemanfaatan layanan. Selain itu, upaya peningkatan pengelolaan keterbukaan informasi publik dilakukan untuk meningkatkan kualitas layanan seperti 1) Menjaga hubungan baik antarstaf dan koordinasi antar-fakultas dan unit kerja, 2) Meningkatkan koordinasi dengan Gugus Penjaminan Mutu, 3) Melaksanakan pedoman terbaru Peraturan Menteri Pendayagunaan Aparatur Negara dan Reformasi Birokrasi Nomor 14 Tahun 2017, 4) Menambah tiga Kepala Bidang yaitu Kepala Bidang Layanan Informasi, Kepala Bidang Keluhan dan Survei Pengguna, serta Kepala Bidang Pemetaan Verifikasi dan Integrasi Data.
\end{abstract}


Kata Kunci: Keterbukaan informasi publik; Manajemen informasi; Pejabat pengelola informasi dan dokumentasi; Universitas

\section{INTRODUCTION}

The industrial society that Developed over the past few decades has evolved to information and knowledge society. It is caused by Information and Communication Technology (ICT) advancement that easier public access. Furthermore, its development has affected many industrial sectors in society, such as the economy, social, culture, politics, and education. In advance information and knowledge society, the important thing in social life is pattern, culture, and existence of information.

Information has been the primary need of each person to develop individual quality and enhance communication in social life. Information access, including human rights, is guaranteed and protected by the constitution. It listed on second amendments of 1945 Constitution Article 28F that state, "Each person entitled for communication and getting information for personal and social environment development and entitled to search, own, store, manage, and share information using all available channels."

Each person needs information with the level of their needs and backgrounds. Information can be obtained through various ways such as official websites and social media, according to the field. In the information society era, information need is increasing and out of control. Therefore, society encourages the government to enhance information quality and build information culture. In democratic countries, recognition of information right is considered a means of monitoring and supervising administration of public bodies.

Best practice for integration of the solution in each problem of information usage is to meet organization and user need that served (Hendrawan 2016). This practice balances an organizational commitment to openness and transparency with significant responsibility (Hendrawan \& Ulum 2017). It shows orientation and general practice on the organization with attention to information that is created, used, and distributed. Pendit and Hendrawan (2019) stated politic and information cultural could not be divided from culture roundly, in which information culture related to attitude on information and their distribution, while politic culture deals with orientation and attitude on authorities and their distribution.

In 2008, the Indonesian government initiated socialization of information disclosure movement to all institutions and/ public bodies in Indonesia. It performs by the government to give democratic and transparency impression, refer to the government of the people, by the people, for the people. By opening public information disclosure access, public bodies can be expected motivated to responsible and oriented of excellent service for the public interest.

Currently, information disclosure continuities have been supported by Act Number 14 Year of 2008 (Undang-Undang Keterbukaan Informasi Publik/UU KIP). UU KIP was approved on 30 April 2008 and enacted on 30 April (Komisi Informasi Pusat RI, 2010). According to UU KIP, public information disclosure is a facility on optimization monitoring on the implementation of state, other public bodies, and related to the public interest.

Enactment of UU KIP is purposed to bring information management changes. Before enacting UU KIP, implementation of public information management performs with closed paradigms; it means all information is closed unless permitted open. After the enactment of UU KIP, there is a paradigm shift, 
such an information management shift to open information management; it means all information open unless for classified information. It shows the following illustration below:

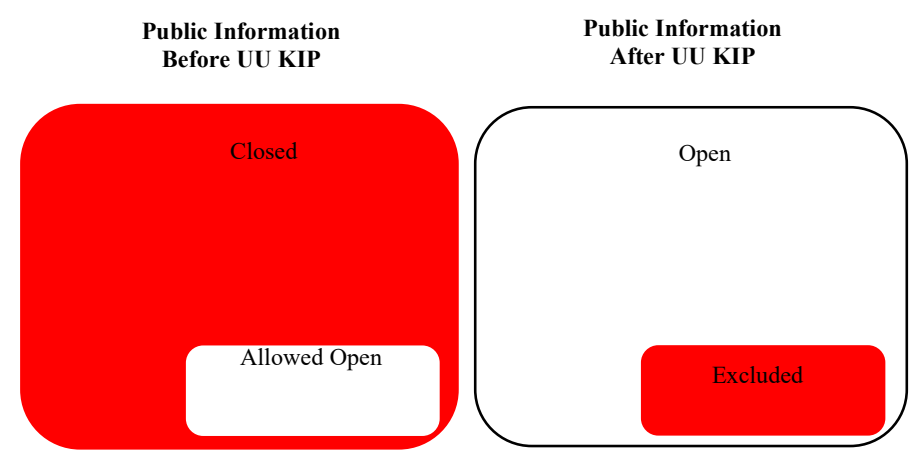

Figure 1. Public information paradigm changes (Source: Dipopramono, 2017)

Figure 1 shows the difference between public information before and after the enactment of UU KIP. For classified information, Public bodies must first conduct a consequence test of consequences that arise when information is made public. However, that does not mean information that is classified cannot access by the public. Classified information can be obtained to adequate that have been created by public bodies by considering purpose and objectives from information users.

Information and Documentation Management Officer (IDMO) is one of the public bodies that respond to information disclosure. IDMO is responsible for storing, documenting, and providing information services in a Public Agency (UU KIP). The existence of IDMO on each public body has given convenience for public bodies to be more transparent to the public. Universitas Brawijaya (UB) is one of the public bodies in Indonesia with IDMO to support information disclosure. UB also has Information, Documentation and Complaint Officer (IDCO) to support information disclosure and fundamental principle of university comprising education, research and community services (Tridharma Perguruan Tinggi).

UB received second place in 2014, first place in 2015, and second place in 2016 for public information disclosure (Universitas Brawijaya, 2016). In 2019 UB received an award and first ranked for the same category. UB received the highest scores of public information disclosure that included an informative category (Universitas Brawijaya, 2019).

Table 2. Ranking under the category of Public University Institutions in 2019

\begin{tabular}{|l|l|l|}
\hline No & Ranking and State University & Qualification \\
\hline 1. & Universitas Brawijaya & Informative \\
\hline 2. & Universitas Negeri Malang & Towards Informative \\
\hline 3. & Universitas Indonesia & Towards Informative \\
\hline 4. & Universitas Negeri Padang & Towards Informative \\
\hline 5. & Universitas Negeri Padjajaran & Towards Informative \\
\hline 6. & Universitas Pendidikan Indonesia & Towards Informative \\
\hline
\end{tabular}

(Source: Universitas Brawijaya, 2019)

Provision of useful information related to information management process. Good management produces quality output, so public bodies need to pay attention to information management in each 
organization. Management is origin from manage that means to lead, control, organize, and cultivate to be better, more advanced, and responsible for their works. Salim and Salim (2002) said management is a process that helps formulate wisdom and purpose, giving control to all the things involved in the implementation and achievement of goals. It concludes that governance is a process of use and utilization of all resources directed to achieve organizational goals.

Satriawan and Lutfi (2014) state that public information management is an effort to organize or manage information obtained from these public bodies. It means information can manage to be library collection or follow up of their information. Good management is fundamental to each organization's development. Good management identifies organization that has fulfilled requirements and show that organization worked according to public interest. Terry (2012) states that good management compromises four processes, such as planning, organizing, actuating, and controlling.

Management is an essential thing in providing information processes in university and other public bodies. Implementation of public information disclosure process needs attention of standard operational procedures (SOP) to produce an output of information service quality. The national information management and documentation guidelines from the Ministry of Communication and Information of Republic Indonesia (2010) explain four mechanisms on information governance: information collection, information classification, information documentation, and information services. However, this study wants to explore procedures and efforts to improve the management of public information disclosure. This study also discusses supporting and inhibiting factors of the management of public information disclosure in UB. This study is expected to give thought contribution and reference material for policymakers and further research, especially those related to public information disclosure.

\section{LITERATURE REVIEW}

\subsection{Related Works}

Khadafi and Lawanda (2014) discussed the management of public information services of IDMO in Ministry of Communication and Information Republic of Indonesia as the implementation of UU KIP. This study uses qualitative approach with case study. Data collection is participative observation, indepth interview. The study result shows IDMO has performed its responsible and task in management public information services, which is compromising acquisition, classification, consequence test, store and documentation, dispute resolution, public information dissemination according to legislation provisions.

Hastuti, Setiawan, and Safitri (2015) discussed IDMO and public information disclosure implementation in Riau Local Government. This study used descriptive qualitative approach. Study results show lack of information in Rehabilitation of Unfit for Living (rehabilitasi rumah tidak layak huni /RTLH) program that holds by Poverty Reduction Coordination Team (Tim Koordinasi Penanggulangan Kemiskinan /TKPK). It caused lack of UU KIP knowledge and IDMO No. 17 Year of 2013, Guidelines of documentation, and information services in Riau Local Government.

Supriatna (2016) discussed the understanding and meaning of IDMO and public information disclosure implementation in Banten local government. This study uses qualitative approach with phenomenology. Study results show understanding of IDMO and public information disclosure implementation already well. IDMO has performed extrapolation, such as viewing that is behind, what is written, and what capabilities will occur as an enactment result of UU KIP. 


\subsection{Open Government}

According to Susmarto (2009), open government is government/society practice and methods that organized resources and solving public problems. To created open government, the government must perform principles that promote good relations between government and society. Andrianto (2007) stated, eight principles have to perform by government, such as public participation, upholding of law supremacy, transparency, awareness to stakeholder, consensus orientation, equality, effectivity, efficiency, accountability, and strategic vision. It concludes, open government principles purpose to create trust from society. Their trust created from government transparency on making decisions, so society will be active to participate in every activity and making decisions.

Dipopramono (2017) stated that participation in government management of open government involved society in every making decision on using public resources and solving problems that have purposes to state development. Kierkgaard on Solehati (2010) Public office is a contract that, in return for public trust, must secure the utmost commitment from public officials and politicians to remain loyal and dedicated to the interests of the people they serve. It concludes that open government is an effort to take public trust with involved society in decision making and creating transparency government. Moreover, to create transparency government, the main requirement is creating public information disclosure and public participant in making decisions.

\subsection{Public Services Management}

Gibson, Donelly, and Ivancevich on Ratminto and Winarsih (2005) states, management is a process that performs by one or more people to the coordination of various activities to achieve goals. Hadari (2003) describe that management is a series of process that is comprising of planning, organizing, actuating, controlling, and budgeting.

According Moenir (2002) service is an activity that performs by individual or group with a particular foundation where the level of satisfaction can only felt by the person serving or being served, depending on service provider ability to meet user expectations. Ratminto and Winarsih (2005) state: services management is a process applied knowledge and art to arrange plan, implemented plan, coordination, and completing services activity to achieve service goal that has firm and friendly to user, creation of particular interactions, and quality control with users. Public service management is a series of process that is comprising of planning, organizing, actuating, controlling, and budgeting. It purposes to give the best services according to basic rules and procedures set.

\subsection{Public Information Disclosure}

According to Buckland (1991), information has three meaning, such as 1) information as process; 2) information as knowledge; 3 ) information as thing. Public information disclosure is a breakthrough because, in the course of its journey, information that was initially difficult to obtain has now become easier to access. UU KIP makes public bodies required to provide information that is needed by society according to their field. In public information disclosure, not all information in public bodies is open and accessed by the public. Generally, information type divides into two types, public information and classified information.

\subsection{Information and Documentation Management Officer (IDMO)}

Public bodies are the main actor in the implementation of public information disclosure refer to UU KIP and derivative regulations. Public bodies are executive, legislative, judicial agency, and other agencies 
that have function and primary duties related to state administration, whose funds partially or entirely originate from the regional revenue and expenditure budget, public donations, and abroad.

One of public body leader actors that have tasks for manage information is IDMO. Every public body must appoint an IDMO, to support fast, precise and straightforward services. It regulated in Article 13 UU KIP. IDMO is a term and new official that have responsibility to store, documentation, provision, and information services field in the public bodies.

IDMO assisted by functional official that give documentation and information services, making information collection and documentation, and documentation and information system development. In UB, IDMO assisted by IDCO as functional official that gives information services to the public. IDCO collaborates with IDMO is to provide information disclosure to easily accessible to the public. All activity and work programs that perform by IDCO is all come from IDMO referrals.

\subsection{Management of Public Information Disclosure}

Satriawan and Lutfi (2014) state that management of public information disclosure is an effort to arrange or manage information that has got from public bodies. It means information can manage to be documentation or follow up from their information. According to Terry (2012), good management is management based on the four processes, such as planning, organizing, actuating, and controlling.

In particular, every public body has unique management and often different from other public bodies. To create quality and good management, the institution needs to consider four processes of management. Furthermore, there are six elements of management (6M), such as Men, Money, Methode, Materials, Machines, and Market (Robbins \& Coulter, 2007). It concludes management of public disclosure is information control process to formulate policy with planning, organizing, actuating, controlling, and their element to achieve institutional goals.

The Information Management and Documentation National Guidelines from Ministry of Communication and Information Republic of Indonesia (2010) states, there are four mechanisms on information management such as information collection, information classification, information documentation, and information services. Each mechanism has roles in creating public information disclosure, ideally.

\section{METHOD}

This study implements case study with qualitative approach. Case study is qualitative approach that explores reality-life, system of limited case, or any case, through collected detail and in-depth data, involved many information sources, and reported case description and theme (Creswell 2015). Data was collected by participative observation, interviews with five key informants, collecting documents, and audio-visual. In participative observation, the researcher observes directly and take notes on the research objects. Semi-structured interviews used to get the primary source. The study focuses on management of information disclosure, include:

1. Management of public information disclosure in UB,
a. Collecting information
b. Information classification
c. Information documentation
d. Information services 
2. Inhibit and supporting factor, and effort to enhance public information disclosure management in UB.

Location in this study is UB that located in Veteran Street, Malang City, East Java, Indonesia. While the study site is IDCO and IDMO UB. This site was chosen as UB received second place in 2014, first place in 2015, and second place in 2016 for public information disclosure (Universitas Brawijaya 2016). In 2019 UB received an award and first ranked for the same category (Universitas Brawijaya 2019). Furthermore, UB has IDMO and IDCO that have responsibility for public information disclosure in UB environment.

The researcher interview five key informants, there are IDCO manager, IDCO secretary, Division of complaint and community satisfaction survey staff, IDCO Staff, and IDCO user. Documents that used in this research are rules and regulations, SOP, related document that collected from IDMO Website, IDCO Website, UB Website, and Ministry of Communication and Information Website. Audio-visual such as audio recording and picture that obtained interview and observation.

Data analysis in this study is using Cresswell (2016), there are: 1) Organize and prepare the data for analysis; 2) Read or look at all the data 3) Start coding all of the data 4) Generate a description and themes 5) Generate a description and themes 6) Write Interpretation of data. Data validity in this research used the triangulation of sources. Triangulation of sources purposed to get many information sources. The researcher can conclude suitability of management of public information disclosure with Operating Standards Procedure (SOP).

\section{RESULTS AND DISCUSSION}

\subsection{General Description of IDMO and IDCO in Universitas Brawijaya}

IDMO of UB was initiate in 2010 through UB Rector's Decree, Number of 157/SK/2010, on 11 May 2010. These decrees change in 2014 through UB Rector's Decree, Number of 280, Year of 2014. Adapting current act, in 2017 UB Rector's Decree, Number of 3475, Year of 2017, IDMO is appointed as Information and Documentation Management Officer. Furthermore, IDMO of UB has an official website through http://pidk.ub.ac.id/. This official website provides kind of public information in UB and IDMO and IDCO of UB profile.

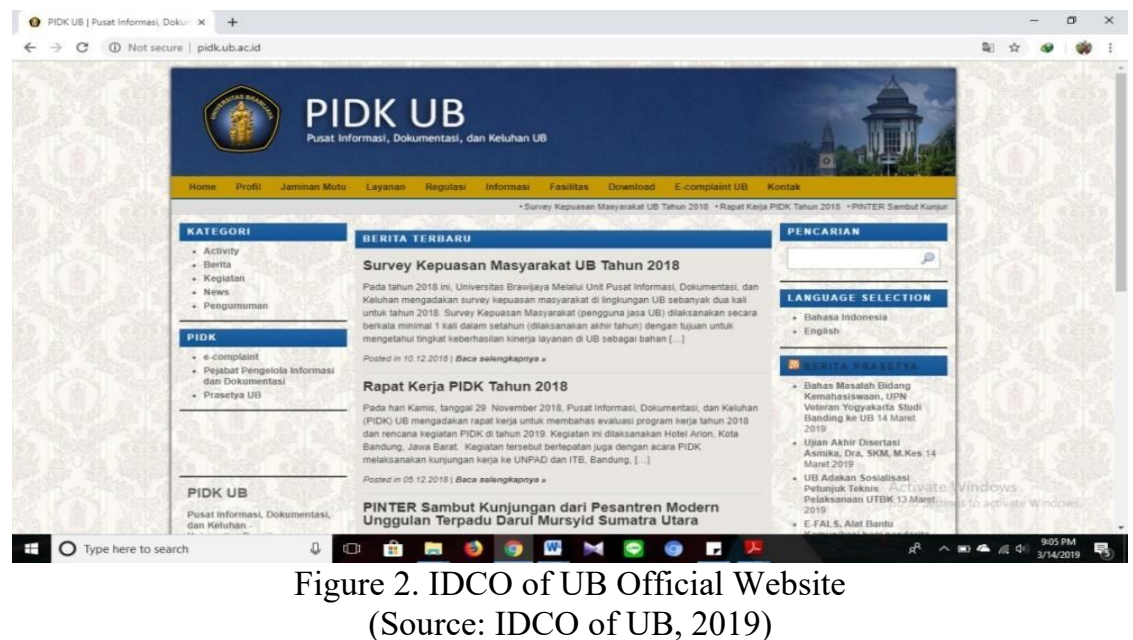

(Source: IDCO of UB, 2019)

\subsection{Procedure of Public Information Disclosure Management in Universitas Brawijaya 4.2.1 Public Information Collection}


Information collection activities that implement by each organization or organization unit purposes to support the implementation of information services. IDCO of UB is collecting information from each layer in UB work units, such as faculty, Postgraduate Program, Bureaus, Institution, Technical Implementing Units, and Business Management Bodies of UB. Its mechanism is similar to guidelines from the Ministry of Communication and Information of Republic Indonesia (2010). There are IDCO must collect data from work units such as Kesekjenan, Itjen, Postel, SKDI, APTEL, BIP, and BALITBANG. This guideline is referencing for public bodies, as generally the guidelines according to UU KIP. Information collection mechanism in IDCO of UB is following figure 2:

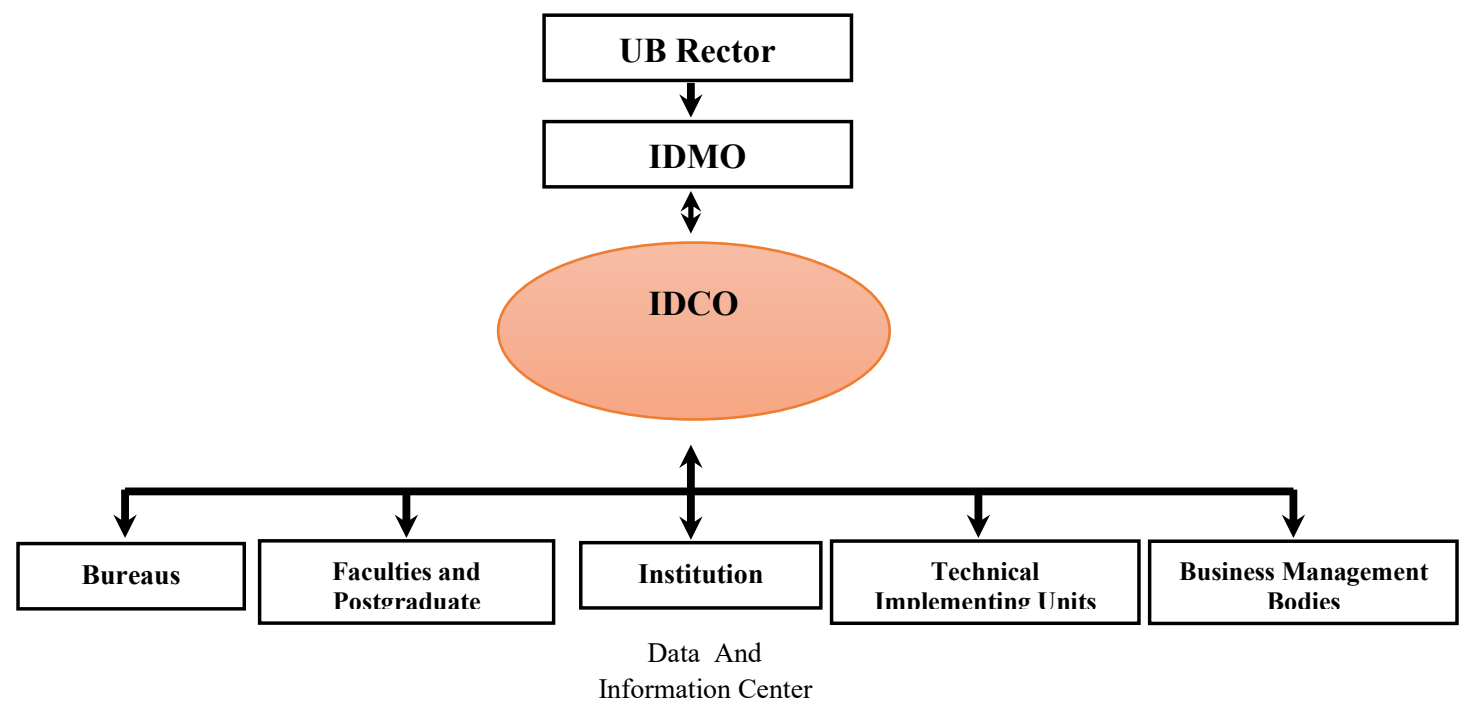

Figure 2. Information Collection Mechanism in IDCO of UB

(Source: IDCO of UB, 2019)

Figure 2 shows

1. Rector is supreme leader

2. Any information in work units is unit leader responsibility

3. Any information that manages in work units is unity of information from each work unit under it

4. Any public information each work unit delivered to IDCO of UB to organize by IDMO of UB

5. Any public information that received by IDCO of UB, organized and provide for the interests of information services under the IDMO of UB

6. Two-way arrows indicate both parties have right to request information that needed by each work unit

Furthermore, information collection in IDCO of UB divides two ways, such as routine information and unreachable information. 1) Routine information is information that must be available, collect, manage, and provide through online media or storing data for user. Routine information is information needed by the public such as student, lecture, staff and society. Routine information is collected by sending a letter of information request to information owner. As acknowledged by one of the informants: "Each year, we collected data to created annual book. Data collected from UB work units. For example, data of library collection, we must send a letter of information request to UB Library. (AP). 2) Unreachable information is information that has not entered into IDCO, so IDCO first processes information with sending a request letter according to information required. This explanation, according to IDCO Staff: "There are data that not entered into IDCO. For example, the user needs participant data in the Language Development Unit. IDCO will request the data to the Language Development Unit, and giving 
the data to user when data are available to access." (AP). IDCO Secretary added: "To get public information from work units under UB environment, IDCO sent a letter of information request. Information that has collected given to users when needed". (RY)

To get information or data from organization or work unit, between IDCO and user must send a letter of information request to information owner. IDCO manager state: "Similarly with user that ask information to IDCO, user must bring letter of information request or we provide them. IDCO must send letter of information request to works unit such a faculty that have information." (TJ). IDCO implement validity for information collected from information source to provide validity of data. It refers to two of informants, "Data that collected will be checked and confirmed to information owner. For example, information on the annual book, we will confirm validity of information before annual book published." (AP, TJ). IDCO is also repackaging information for easy to understand by user. Repackaging information created by IDCO signed by the head of the unit or those responsible for the information. Thus, the packaged information can be responsible and trust.

\subsubsection{Public Information Classification}

In IDCO of UB, Public information classification divided into two types, public information and classified information. The first, public information is Type of information responsible for providing every time without any request from public. Public information divided into three categories, there are 1) Public information which responsible for providing and announcing period. For example, information that related by public bodies, activity and public bodies perform, financial report and other information that regulated in statute 2) Public information which must be announced necessarily. For example, event and announcement that provide in UB website. 3) Public information must be available at all times. For examples a list of public information, result of public bodies decision, policy, work plan, public bodies agreement, work procedure and public information access report.

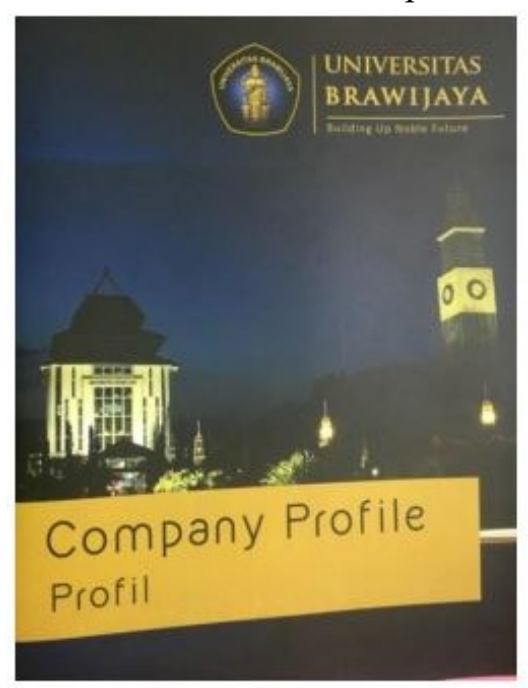

Figure 3. Company Profile of UB

(Source: Researcher documentation, 2019)

Figure 3. shows example of Public information which responsible for providing and announcing period in UB. Company Profile of UB is available in printed form/book which provides to all user. This book contains UB profile such as the head of university, faculty, department program, facilities, library, and other information. 
The second, classified information is information that not available for public, strict, and limited. There are three principles in classified information such as stricted, limited, and not absolute. Strict is to category classified information that must refer to valid methods and objective. Limited, classified information must limit on specific information to avoid subjectivity and arbitrariness. Not absolute, there is no classified information when the greater public interest wants it-classified information. For example, directory of UB Manager contains personal information, picture, telephone and address. It must be protected according to Article 17 of UU KIP.

IDCO staff state "there are two information, public information and classified information. Public information divided into three categories, such as Public information which must be available at all times, Public information which responsible for providing and announcing period, and Public information which must be announced necessarily..." (AP). IDCO secretary also added: "Type of information refers to UU KIP. Public information regulated in article 17 and classified information regulated in the article 18. Public information divided into three categories of public information, regulated on UU KIP, Article 9, 10 and 11. This information is available in IDCO website...." (RY).

Public information and classified information in particular regulated on Standard Operational Procedure (SOP) Number of UN10/CO2/05/HK.01.02.a/007 which contain classified information through consequences test and SOP Number of UN10/CO2/05/HK.01.02.a/006 which contain establishment of public information list. This SOP implemented by IDCO of UB to perform information classification process. Moreover, IDCO of UB also implemented information classification that refers to UU KIP, such as Public information regulated in the article 17 and classified information regulated in the article 18. Public information which responsible for providing and announcing period regulated in article 9 of UU KIP, Public information which must be announce necessarily regulated in article 10 of UU KIP, Public information which must be available at all times regulated in article 11 of UU KIP.

\subsubsection{Public Information Documentation}

IDMO of UB as data and information center have performing documentation process. The documentation process is vital for data and information retrieval. Therefore, IDMO of UB needs to pay attention to standard operational procedures (SOP) on documentation process. In documentation process, there is a different process between public information and classified information. Information documentation in IDMO of UB is following information documentation SOP. There are public information flows:

a. IDMO of UB executor leads assistant team for documenting public information

b. IDMO of UB executor assistant team created and delivered letters to each works unit leader that has public information for delivered their information

c. Works unit leaders received public information request letter, delivered information to IDMO of UB executor assistant team

d. IDMO of UB executor assistant team received duplicate public information from works unit leaders and compiling them.

e. IDMO of UB executor assistant team was finalizing compilation of public information and prepared them to organize university statistic documents.

IDMO of UB is cautious in documenting data and information. Documentation of public information performs in two methods; there are: a) manual documentation, which is documenting data and information by a printing method. IDMO of UB also has a filing and databases system to store data and retrieve the information in printed and digital form. Data and information are organized by year to make 
it easier for information retrieval. Manual documentation is comprising of three types. There is documentation of public information and classified information, documentation of complaint results, and documentation of public satisfaction. IDCO staff said: "We have filling cabinet to store letter and information. For print paper, we put in ordner and arranged according to year and field.." (AP). Division of complaint and community satisfaction survey staff added, "in the filing cabinet, we have three-section, for archive or documentation of public information services, community satisfaction survey and e-complaint." (UA).

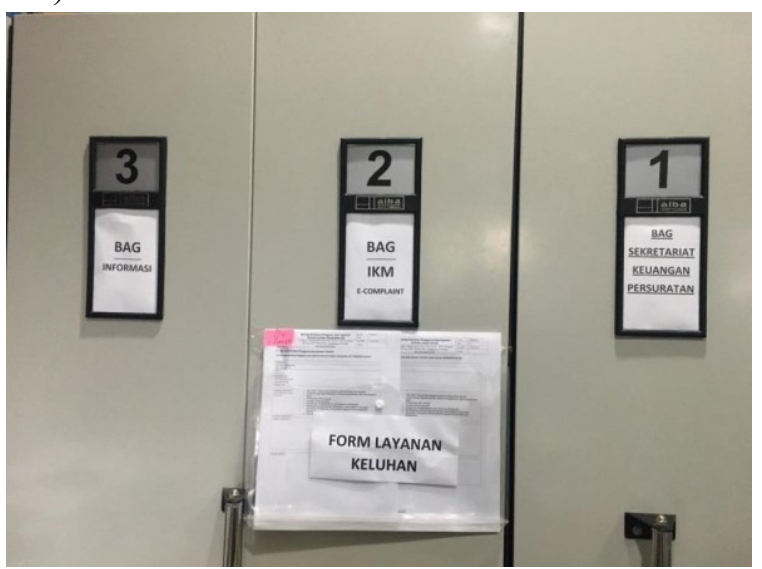

Figure 4. Filling cabinet in IDCO of UB

(Source: Research documentation, 2019)

b) digital documentation, which is documenting data and information by storing on the server. IDMO of UB has specific computer to store data and information in digital form. IDCO of UB divided digital documentation into three sections. There is documentation of classified information, documentation of complaint result, and documentation of community satisfaction survey. It was explanation by IDCO staff: "digital form can send by email and store by computer. We can store on the second floor, IDCO room.." (AP). It evidences support by Division of complaint and community satisfaction survey staff: "for electronic form, we stored in computer. The documentation of information performs by two methods, non-electronic and electronic (digital).

\subsubsection{Public Information Services}

Public services are an effort to provide information for the public. In providing public services, there are needs to be well understood by information providers and users, such as understanding information services flow and its mechanism. In IDCO of UB, there are two information services, such as public information services, and public satisfaction survey and compliant services.

\section{a. Information and Documentation Management Services}

Information and documentation management services (PINTER) has a task to manage data and information in UB, providing user service for the academic community of UB and others. There are two types of information, public information, and classified information. Public information is information available for public access without requesting information formerly. While classified information is information that has limited access when classified information open, there are causing problems for individual and institution related to the owner/creator of classified information.

IDCO of UB follows mechanism of public information services. User must fill out request form that provided by Pinter staff. The form contains applicant identity, required information, purpose of using information, how to obtain, and duplicate information. In order to request information, user must fill out 
form and copy of identity card as archive of user request. Information will be accountable to user. The form also contains the purpose of submitting a request for information. It explains by IDCO staff: "...We provided form to user when they request information. We provide print form and online form that can be download and filled out by user from our website. We request copy of identity card as information request evidence". (AP). It supports by user opinion: "When I visited PINTER, I asked IDCO staff. I got a form that contains identity, information need and reason to get information request. I filled out request form and give it to IDCO Staff with copy of identity card. It will be processed on 1-2 weeks". (YD). The other user also supports this statement: "We must know information and purpose that we need. There was IDCO staff that gives information request form to fill out. It contains identity, information need and reason to get information request. The request form submitted to IDCO Staff and we will wait to get agreement of IDCO manager. We will contact by IDCO staff through email according to request information from" (MI).

\section{b. Division of Complaint and Community Satisfaction Survey Management Services}

Division of complaint and community satisfaction survey management services is a division that has a task for serving complaints, suggestions, and critics from both the academic community and the wider community. IDCO of UB Staff handles this Division and aims to perform survey and connect between users and UB itself. Division of complaint services accommodates all of complaints from users. Not only complaint but also accommodate user aspirations such as suggestions and constructive criticism. IDCO staff added, "We have E-complaint as tools to accommodate aspiration for users, such as complaint, suggestions and critic." (UA).

Complaint services regulated on SOP UN10/CO2/05/HK.01.02.a/05 Delivering compliant services. Mechanism of complaints deliver are following:

a) User sent complaints through UB complaint service system to https:/e-complaint.ub.ac.id/ and national complaint to http://lapor.go.id/ or visit IDCO of UB Secretariat.

b) IDCO of UB verify and clarify full complaints: feasible or not to be followed up, and verify where the complaint addressed

c) IDCO of UB deliver complaint to faculties or works unit in UB environment through ecomplaint system and will receive by e-complaint operator.

d) E-complaint operator in faculties or works unit level deliver the complaint to faculty manager or works unit

e) Manager or authorized official in faculties or works unit give writing answer complaint with form format according to e-complaints system/LAPOR system and deliver to e-complaint operator in faculties or works unit

f) E-complaint operator in faculties and works unit level is inputting answer to e-complaints system/LAPOR system that delivers through mail to IDCO of UB

g) IDCO of UB verify repair results and remind faculties and works unit that has no response to their complaints

h) IDCO of UB changes complaint status to finish, according to the answer to e-complaint system and LAPOR system. User can check their complaint status in this system.

i) IDCO of UB collaborates with verifying team to verify complaint if needed. In this case, it usually applies to follow-up complaints that are still in promises form. If the complaint were resolved, the complaint status would change to finish; if not, it will remain in open status.

j) IDCO of UB arrange and deliver a result of user complaint compilation to IDMO of UB executor every quarter and once a year 
k) IDMO of UB executor receives a result of user complaints compilation to IDMO of UB executor every quarterly.

UB provides not only e-complaint services for UB user but also available for public. The purposes of ecomplaint are to accommodate and connect user with UB. E-complaint is available in each faculty and work units. It was monitoring to answer and finish complaint on time. Faculties and work units are responsible for creating complaint report and sent it to Manager. Pinter Staff added: "We just connector between user and UB, support and coordinate user complaint to finished necessary. The complaint will execute by faculties and work units.

\section{c. Division of Community Satisfaction Survey Service}

Division of community satisfaction survey service in UB is one of Division that responsible for performing community satisfaction survey. Community satisfaction survey has function to measure community satisfaction level on public service perform. IDCO of UB create and provide questionnaires distributed to the faculties and works unit in UB environment. Usually, this Division provides 5.0006.000 questionnaires and distribute $10 \%$ in faculties and works unit. Duration of filling out the questionnaire questionnaires is two weeks until one month; then questionnaire is sent to IDCO of UB. Result of community satisfaction survey related to e-complaint. When complaint has a good reason, it enhances the perform of service and community satisfaction survey.

\subsection{Inhibiting Factor, Supporting Factor and Effort to Enhance Public Information Disclosure}

\subsubsection{Supporting Factor}

The main factor that supports public information disclosure services is support from rector and each faculty and work unit manager. Rector has the power to support process of public information disclosure services. Faculties and work units need support and authority from Manager to perform their task. IDCO staff state: "Manager is one of supporting factor. University manager gives good support; We can manage and collect data rapidly. We will get the problem when Manager does not support our services". (UAS). It also supported by IDCO manager: "Commitment of UB manager to support IDCO development, such as policy for public information disclosure and IDCO development. We have coordination with Division of research, education and quality management (LP3M) to enhance community satisfaction, quality and public trust." (TJ)

Internet network and e-complaint system are supporting factor to perform IDCO services. Usage of ecomplaint system support by Division of information technology (IT). This system is running well because of the facilities, IT division and IDCO human resource that manages the system. It according to IDCO Secretary: "We have good internet network and e-complaint system that supports by IT division". (RY, UA).

\subsubsection{Inhibiting Factor}

The obstacle of public information disclosure management in UB is not all faculties or work units that manage and organize information well. It impacts information request, when information is not managed, collecting information will need more time. For example, when IDCO of UB needs data of student award in faculty. Faculty have no performed information management. will search data slowly. It supports by IDCO staff: "Inhibiting factor is faculties or work units has not performed information management. It impacts for information retrieval when we need data from it" (AP). 
Furthermore, few students have not taken advantage of e-complaints, and several managers or staff that have not information management background that makes IDCO of UB educate them. It supports by IDCO staff: "few of student afraid to use e-complaint, there are name and student ID number that filled out in e-complaint. It actually, we keep and protect private data. However, we perform socialization and education to student and faculty or work unit manager. It can be solution to enhance the usage of e-complaint and give the solution.

\subsubsection{Effort to Enhance Public Information Disclosure}

Increasing public interest makes public information service institutions such as IDMO of UB and IDCO of UB need to enhance quality services. Several efforts are being made by IDMO of UB and IDCO of UB to improve the quality of information services, Such as:

1) Establish good relations between staff, enhancing coordination between faculties and work units in the UB environment. It supported by IDCO Staff: "Staff relationship, communication and understanding job desk is an important factor to enhance public information disclosure. We try to minimize miscommunication and error on managing data. In the other hand, we need to keep a good relationship with faculties and work units. There are data that we must provide to user.

2) Increasing coordination with Manager and Quality Assurance Unit (QUA) to enhance solution of each complaint, suggestion, and recommendation in e-complaint. It according to IDCO Staff: "It related, QUA can support and control quality of e-complaint. We perform to give solution of complaint, and it can be effort to assessment of community satisfaction survey." (UA).

3) Community satisfaction survey used new statute, from Regulation of the Minister of Administrative and Bureaucratic Reform Number 16 of 2014 to Regulation of the Minister of Administrative and Bureaucratic Reform Number 14 of 2017.

4) Increasing human resource. There is three-division manager that taken from lecturer, such as Manager of information services, the Manager of user complaints and survey, and Manager of verification and data integration mapping. The Manager legalized and appointed on 1 April 2019. This Manager performs to support IDCO in managing data and services. It supported by IDCO Secretary: "We added three-division manager from lecturer. They have position as Manager of information services, the Manager of user complaints and survey, and Manager of verification and data integration mapping. We need human resource that has managing data skill. It legalized on 1 April.

\section{CONCLUSION}

Management of public information disclosure that implementation in IDMO of UB and IDCO of UB is relevant to general statute in Indonesia. Four processes in the management of public information disclosure by IDMO of UB and IDCO of UB show 1) Information collection is in line with Information Management and Documentation Guidelines from Ministry of Communication and Information Republic of Indonesia. IDMO of UB and IDCO of UB have good coordination with work unit's management such as bureaus, faculties, institution, research center, holding and business center as information sources. 2) Information classification is in line with UU KIP that divided into two categories: public information and classified information. 3) Information documentation that has implemented are printed and digital storage system. In digital system, data and information saved in a specific server for storing. Data and information are saved by Type of information and organize by years. 4) Information services consist of information and documentation management services, and public satisfaction survey and compliant services. 
Information services supported by UB Rector and e-complaint system and internet network to support services activity. While inhibiting factor are lack of management in faculty or work unit that impact IDCO need more time on serving users and lack of socialization to the academic communities made this service was yet utilized optimally. UB makes an effort to realizing management of public information disclosure with improving coordination within faculties and work units. UB was also following current act and adding three head division (information services, public satisfaction survey and complaint services, and mapping verification and data integration division) to support their services. For suggestions, UB needs more socialization about information services such as PINTER and e-complaint that are rarely accessed by students. UB also needs to develop a mobile application to support and facilitate information services.

\section{BIBLIOGRAPHY}

Andrianto, N. (2007). Good e-government : Transparansi dan akuntabilitas publik melalui egovernment. Bayumedia Publishing.

Buckland, M. (1991). Information as thing. Journal of the American Society of Information Science, 42(5), 351360.

Creswell, J. W. (2015). Penelitian Kualitatif dan Desain Riset:memilih di antara lima pendekatan (3rd ed.). Pustaka Pelajar.

Dipopramono, A. (2017). Keterbukaan dan sengketa informasi publik: Panduan lengkap memahami open government dan keterbukaan informasi publik, serta praktik sengketa informasi publik. Renebook.

Hadari, N. (2003). Manajemen sumber daya manusia untuk bisnis yang kompetitif. Gadjah Mada University Press.

Hastuti, R., Setiawan, R., \& Safitri, D. P. (2015). Keterbukaan informasi publik oleh pejabat pengelola informasi dan dokumentasi pada Dinas Sosial Provinsi Kepulauan Riau. http://jurnal.umrah.ac.id/wpcontent/uploads/gravity_forms/1-ec61c9cb232a03a96d0947c6478e525e/2015/09/JURNAL-PDF5.pdf

Hendrawan, M. R. (2016). The Application of Knowledge Management in The United States Agency for International Development ( USAID ). Record and Library Journal, 2(1), 64. https://doi.org/10.20473/rlj.v2-i1.2016.64-71

Hendrawan, M. R., \& Ulum, M. C. (2017). Pengantar Kearsipan: dari Isu Kebijakan ke Manajemen. Universitas Brawijaya Press.

IDCO UB. (2019). Pusat Informasi, Dokumentasi, dan Keluhan Universitas Brawijaya. http://pidk.ub.ac.id/

Khadafi, M. F., \& Lawanda, I. I. (2014). Pengelolaan Layanan Informasi Publik Pejabat Pengelolaan Informasi dan Dokumentasi (PPID) Kementrian Komunikasi dan Informatika Republik Indoenesia . http://www.lib.ui.ac.id/naskahringkas/2016-11//S58603-Mohammad Faqih Khadafi

Kominfo. (2010). Tanya jawab standar layanan informasi publik. Kreasi Agung Abadi.

Kominfo. (2017). Laporan penyelenggaraan kegiatan penganugerahaan keterbukaan informasi badan publik tahun 2017. Komisi Informasi Pusat Republik Indonesia.

Kominfo. (2018). Laporan implementasi keterbukaan informasi publik \& penganugerahaan keterbukaan informasi badan publik tahun 2018. Komisi Informasi Pusat Republik Indonesia. https://ppidkemkominfo.files.wordpress.com/2018/11/laporan-penganugerahan-2018_ok_2_final.pdf

Moenir. (2002). Manajemen pelayanan umum di Indonesia. Bumi Aksara.

Pendit, P. L., \& Hendrawan, M. R. (2019). Budaya informasi dan keterbukaan informasi: Sebuah pendekatan implementasi Undang-Undang Nomor 14 tahun 2008 tentang Keterbukaan Informasi Publik dan dampaknya terhadap manajemen informasi di lembaga publik. In M. R. Hendrawan (Ed.), Bunga Rampai Menuju Tata Kelola Informasi: Sebuah Antologi Kepustakawanan. ISIPI Press.

Ratminto, \& Winarsih, A. S. (2005). Manajemen pelayanan. Pustaka Pelajar.

Undang-Undang Dasar 1945 Pasal 28F, (1945).

Undang-Undang Nomor 14 tahun 2008 tentang Keterbukaan Informasi Publik, (2008).

Peraturan Menteri Komunikasi Dan Informaika Nomor : 10/PER/M.KOMINFO/07/2010 Tentang Pedoman Pengelolaan Informasi Dan Dokumentasi Di Lingkungan Kementerian Komunikasi Dan, (2010).

Peraturan Menteri Pendayagunaan Aparatur Negara dan Reformasi Birokrasi No. 16 Tahun 2014, (2014).

Peraturan Menteri Pendayagunaan Aparatur Negara dan Reformasi Birokrasi No. 14 Tahun 2017, (2017).

Robbins, S. P., \& Coulter, M. (2007). Manajemen. Indeks.

Salim, P., \& Salim, Y. (2002). Kamus bahasa Indonesia kontemporer. Modern English Press.

Satriawan, M. I., \& Lutfi, M. (2014). Meneropong Komisi Informasi Publik. UB Press.

Solehati, N. (2010). Kesiapan Universitas Gadjah Mada untuk melaksanakan Undang-Undang Republik Indonesia Nomor 14 tahun 2008 tentang Keterbukaan Informasi Publik. Universitas Gadjah Mada. 
Sumarto, H. S. (2009). Inovasi, partisipasi dan good governance: 20 prakarsa inovatif dan partisipatif di Indonesia. Yayasan Obor Indonesia.

Supriatna, K. (2016). Kontra produktif keterbukaan informasi publik. http://ejurnal.lppmunsera.org/index.php/LONTAR/article/view/362

Terry, G. R. (2012). Prinsip-prinsip manajemen (J. Smith (trans.)). Bumi Aksara.

Universitas Brawijaya. (2016). Universitas Brawijaya Raih Peringkat II dalam Pemeringkatan Keterbukaan Informasi Badan Publik Tahun 2016. https://ppid.ub.ac.id/2016/12/20/ub-raih-peringkat-iipemeringkatan-keterbukaan-informasi-2016 